\title{
Further studies of a staggered hybrid zone in Mus musculus domesticus (the house mouse)
}

\author{
JEREMY B. SEARLE, YOLANDA NARAIN NAVARRO* \& GUILA GANEM $\dagger$ \\ Department of Zoology, University of Oxford, South Parks Road, Oxford OX1 3PS,U.K.
}

\begin{abstract}
In the extreme north-east of Scotland (near the village of John o'Groats) there is a small karyotypic race of house mouse $(2 n=32)$, characterized by four metacentric chromosomes $4.10,9.12,6.13$ and 11.14. We present new data on the hybrid zone between this form and the standard race $(2 n=40)$ and show an association between race and habitat. In a transect south of John o'Groats we demonstrate that the clines for arm combinations 4.10 and 9.12 are staggered relative to the clines for 6.13 and 11.14, confirming previous data collected along an east-west transect (Searle, 1991). There are populations within the John o'Groats-standard hybrid zone dominated by individuals with 36 chromosomes (homozygous for 4.10 and 9.12), which may represent a novel karyotypic form that has arisen within the zone. Alternatively the type with 36 chromosomes may have been the progenitor of the John o'Groats race. Additional cytogenetic interest is provided by the occurrence of a homogeneous staining region on one or both copies of chromosome 1 in some mice from the zone.
\end{abstract}

Keywords: chromosomal variation, hybrid zones, Mus musculus domesticus, Robertsonian fusions, staggered clines.

\section{Introduction}

The standard karyotype of the house mouse consists of 40 acrocentric chromosomes. However, deviation from this standard complement has been documented in various parts of the range of the west European subspecies Mus musculus domesticus (Bauchau, 1990). Here we consider the substantial chromosomal variation in the extreme northern part of mainland Scotland, first discovered by Adolph \& Klein (1981) and Brooker (1982). The more recent analyses by Scriven \& Brooker (1990) and Searle (1991) suggest a rather simple pattern to this variation. There is a race having 32 chromosomes centred around the north-eastern village of John o'Groats (Fig. 1) and this race forms a hybrid zone with the much more widespread standard $(2 n=40)$ type. The John o'Groats race is characterized by four metacentric chromosomes: $\mathrm{Rb}(4.10), \mathrm{Rb}(9.12)$, $\mathrm{Rb}(6.13)$ and $\mathrm{Rb}(11.14)$ (nomenclature of Lyon \& Searle, 1989). Each of these metacentrics can most simply be considered to result from a Robertsonian

Correspondence: Dr J. B. Searle, Department of Biology, University of York, Heslington, York YO1 5DD, U.K.

*Present address: Department of Genetics, University of Uppsala, Sweden.

$\dagger$ Present address: Institut des Sciences de l'Evolution, Université Montpellier II, C.C. 064, Place Eugène Bataillon, 34095 Montpellier cedex 05, France.
(Rb) fusion of two ancestral acrocentrics with, for instance, metacentric 4.10 derived by fusion of acrocentrics 4 and 10 at their centromeres (but see Searle, 1991 for discussion of possible involvement of wholearm reciprocal translocations).

The hybrid zone between the John o'Groats and standard races has been studied along the northern coast of Scotland (Fig. 1). The zone consists of four character clines along which the frequency of each metacentric decreases from 1 to 0 from John o'Groats westwards (Searle, 1991). Normally in a multilocus hybrid zone, such character clines are found to occur at the same position (Barton \& Hewitt, 1985). However, along the east-west transect across the John o'Groats-standard hybrid zone the metacentric clines are distinctly non-coincident (Searle, 1991); hence, the contact between these two races is considered to be a 'staggered hybrid zone' (Searle, 1993). In this paper we use new data to consider whether the clines are also staggered in a southerly direction from John o'Groats, and we collate all available information on the hybrid zone in order to consider its origin and evolution. There are now karyotypic data on 262 mice from 48 sites in the vicinity of the zone, making this one of the better characterized contacts between karyotypic races in the house mouse. 


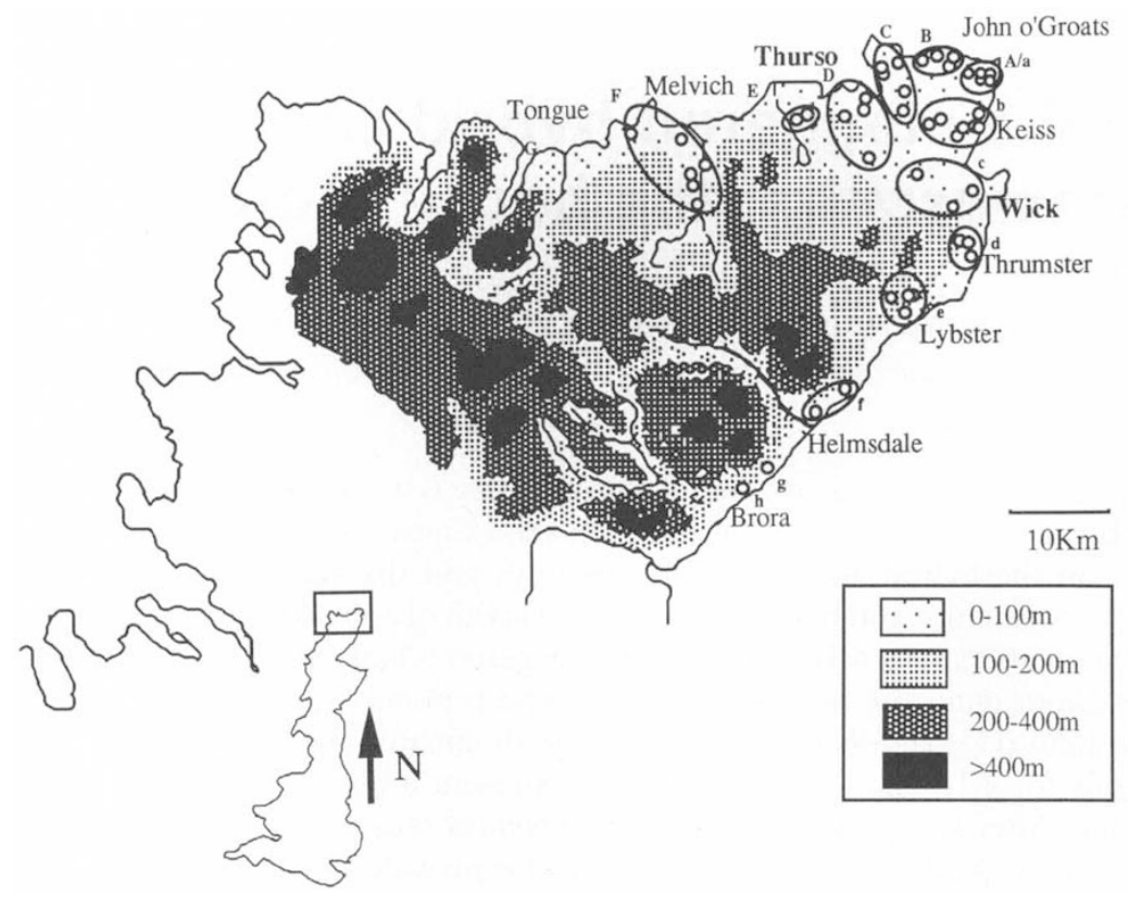

Fig. 1 Location of sites in Caithness and Sutherland where house mice have been karyotyped. Each location is marked by a circle; the manner in which sites are combined together in Table 1 is indicated. The approximate position of coastal towns and villages is also shown on the map. The boundary between the counties of Caithness (to the north-east) and Sutherland runs roughly in a diagonal between Melvich and Helmsdale (see Fig. 1 in Brooker, 1982).

\section{Material and methods}

Two field trips were made during 1992 (24 March-10 April and 15-23 September) to the counties of Caithness and Sutherland in the Highland Region of Scotland. Mice were collected by Longworth live-traps from suitable farms, usually from indoor locations but also from traditional oat stacks (at Sarclet). They were maintained as previously described by Searle (1991). Chromosomal preparations also followed Searle (1991), but some slides of certain individuals were additionally stained by a C-banding method adapted from Sumner (1972).

\section{Results}

Table 1 shows details of metacentric frequency and chromosome numbers at each site sampled in Caithness and Sutherland. Altogether 17 new sites, particularly from the south of John o'Groats, were sampled in the present study, providing a total of 77 mice. Additionally we karyotyped 34 mice from four sites previously sampled by Brooker in ca. 1980 (Seater, Smerlie 3) and/or Searle in 1987 (Seater, Achiemore) or 1989 (Ribigill) (see Brooker, 1982; Scriven \& Brooker, 1990; Searle, 1991). In all cases, the old and new data tallied closely and have been amalgamated in Table 1 .

The sampling localities detailed in Table 1 and Fig. 1 are primarily along the coast of Caithness and Sutherland. Sizeable farms on which house mice breed are restricted to these coastal areas, apart from the low- lying prime agricultural land in the triangle formed by Thurso, John o'Groats and Wick (Fig. 1). Although house mice are probably present in some of the sparse settlements in the central highland areas, their density is likely to be very low compared with the more agricultural coastal strip.

Searle (1991) proposed that there are two chromosomal races of house mouse within Caithness and Sutherland: the John o'Groats race $(2 n=32$; homozygous for metacentrics $4.10,9.12,6.13,11.14)$ and the standard race ( $2 n=40$; all acrocentric karyotype). The distribution of these two types is made clearer by the new data. Sites in the vicinity of John o'Groats are dominated by individuals with 32 chromosomes, while approximately $50 \mathrm{~km}$ away at Melvich (to the west) and Ousdale (to the south) individuals with 40 chromosomes have been found. Further away from John o'Groats the standard race dominates. Thus going south and west chromosome number increases and metacentric frequencies decrease (Figs 2 and 3). However, there were several individuals caught with karyotypes that did not fit in with this geographic pattern (Table 1). Two individuals caught at Auckengill $(2 n=36$; homozygous metacentric for 4.10 and 9.12) and individuals from Lyth, Dunnet 1 and Haster had more acrocentric karyotypes than was normal for their geographic area. Individuals from Shalmstry, Armadale and Brickigore had more metacentric karyotypes than mice from nearby sites.

Our new data support the contention of Searle (1991) that the John o'Groats-standard hybrid zone 
Table 1 The frequencies of variable chromosomes in the house mouse (Mus musculus) at sites in Caithness and Sutherland (see also Fig. 1)

\begin{tabular}{|c|c|c|c|c|c|c|c|c|}
\hline \multirow[b]{2}{*}{ Grid ref.* } & \multirow[b]{2}{*}{ Site† } & \multirow[b]{2}{*}{$N$} & \multirow{2}{*}{$\begin{array}{l}2 n \\
(\text { mean })\end{array}$} & \multicolumn{4}{|c|}{ Freq. of metacentric chromosomes } & \multirow[b]{2}{*}{ Refs $\ddagger$} \\
\hline & & & & 4.10 & 9.12 & 6.13 & 11.14 & \\
\hline & JOHN O'GROATS & & & & & & & \\
\hline $338-/ 972-$ & John o'Groats 1 & 3 & 32.0 & 1 & 1 & 1 & 1 & 2 \\
\hline $3385 / 9723$ & Johh o'Groats 2 & 5 & 32.0 & 1 & 1 & 1 & 1 & 4 \\
\hline $3382 / 9726$ & John o'Groats 3 & 20 & 32.0 & 1 & 1 & 1 & 1 & 4 \\
\hline $3381 / 9725$ & John o'Groats 4 & 4 & 32.5 & 1 & 1 & 1 & 0.75 & 3 \\
\hline \multirow[t]{2}{*}{$3378 / 9732$} & John o’Groats 5 & 2 & 32.0 & 1 & 1 & 1 & 1 & $\mathrm{P}$ \\
\hline & $\begin{array}{l}\text { Combined site A/a } \\
\text { WEST OF JOHN O'GROATS }\end{array}$ & 34 & 32.1 & 1 & 1 & 1 & 0.97 & \\
\hline $3355 / 9724$ & Canisbay & 1 & 32 & 1 & 1 & 1 & 1 & $\mathrm{P}$ \\
\hline $3354 / 9729$ & Seater & 20 & 32.0 & 1 & 1 & 1 & 1 & $2,4, \mathrm{P}$ \\
\hline $3341 / 9729$ & Kirkstyle & 9 & 32.0 & 1 & 1 & 1 & 1 & $\mathrm{P}$ \\
\hline \multirow[t]{2}{*}{$3310 / 9740$} & East Mey & 1 & 32 & 1 & 1 & 1 & 1 & 2 \\
\hline & Combined site B & 31 & 32.0 & 1 & 1 & 1 & 1 & \\
\hline $3244 / 9676$ & Greenland & 1 & 34 & 1 & 1 & 1 & 0 & 3 \\
\hline $3241 / 9643$ & Bowermadden & 1 & 34 & 1 & 1 & 0.50 & 0.50 & 3 \\
\hline $3234 / 9734$ & Brough & 5 & 33.2 & 1 & 1 & 1 & 0.40 & $P$ \\
\hline $3215 / 9714$ & Dunnet 1 & 1 & 37 & 1 & 0.50 & 0 & 0 & 3 \\
\hline \multirow[t]{2}{*}{$3211 / 9713$} & Dunnet 2 & 1 & 34 & 1 & 1 & 1 & 0 & $P$ \\
\hline & Combined site $\mathrm{C}$ & 9 & 33.9 & 1 & 0.94 & 0.83 & 0.28 & \\
\hline $319-/ 968-$ & Castletown & 9 & 34.1 & 1 & 1 & 0.94 & 0 & 1 \\
\hline $3182 / 9666$ & Mains of Olrig & 9 & 34.4 & 0.83 & 1 & 0.83 & 0.11 & 4 \\
\hline $3167 / 9545$ & Spittal & 1 & 36 & 1 & 1 & 0 & 0 & 3 \\
\hline \multirow[t]{2}{*}{$3130 / 9646$} & Shalmstry & 1 & 32 & 1 & 1 & 1 & 1 & 3 \\
\hline & Combined site $\mathrm{D}$ & 20 & 34.3 & 0.93 & 1 & 0.85 & 0.10 & \\
\hline $3071 / 9647$ & Bardnaclavan & 27 & 35.3 & 1 & 0.81 & 0.37 & 0.15 & 3,4 \\
\hline \multirow{2}{*}{$3058 / 9643$} & Westfield & 1 & 35 & 1 & 1 & 0.50 & 0 & 3 \\
\hline & Combined site E & 28 & 35.3 & 1 & 0.82 & 0.38 & 0.14 & \\
\hline $2895 / 9521$ & Bunahoun & 3 & 36.0 & 1 & 1 & 0 & 0 & $\mathrm{P}$ \\
\hline $2894 / 9582$ & Achiemore & 27 & 36.9 & 0.57 & 1 & 0 & 0 & $4, \mathrm{P}$ \\
\hline $2889 / 9574$ & Upper Bighouse & 4 & 36.5 & 0.88 & 0.88 & 0 & 0 & $\mathrm{P}$ \\
\hline $2888 / 9566$ & Laidham & 1 & 38 & 0 & 1 & 0 & 0 & $P$ \\
\hline $2882 / 9647$ & Melvich & 2 & 40.0 & 0 & 0 & 0 & 0 & 3 \\
\hline \multirow[t]{2}{*}{$2790 / 9638$} & Armadale & 1 & 36 & 1 & 1 & 0 & 0 & 4 \\
\hline & Combined site F & 38 & 36.9 & 0.61 & 0.93 & 0 & 0 & \\
\hline \multirow[t]{2}{*}{$2584 / 9539$} & Ribigill (site G) & 28 & 40.0 & 0 & 0 & 0 & 0 & $4, P$ \\
\hline & SOUTH OF JOHN O'GROATS & & & & & & & \\
\hline $3363 / 9643$ & Auckengill & 4 & 34.3 & 1 & 1 & 0.50 & 0.38 & 3 \\
\hline $3278 / 9633$ & Lyth & 1 & 35 & 1 & 1 & 0.50 & 0 & 3 \\
\hline $3289 / 9632$ & Sortat & 1 & 32 & 1 & 1 & 1 & 1 & 3 \\
\hline $3357 / 9627$ & Keiss 1 & 3 & 33.7 & 1 & 1 & 0.67 & 0.50 & $\mathrm{P}$ \\
\hline $3352 / 9625$ & Hawk Hill, Keiss & 1 & 32 & 1 & 1 & 1 & 1 & 3 \\
\hline $3362 / 9623$ & Keiss 2 & 2 & 32.0 & 1 & 1 & 1 & 1 & 3 \\
\hline \multirow[t]{2}{*}{$3341 / 9615$} & Middle Keiss & 2 & 32.0 & 1 & 1 & 1 & 1 & 3 \\
\hline & Combined site b & 14 & 33.2 & 1 & 1 & 0.75 & 0.64 & \\
\hline $3257 / 9550$ & Lower Strath, Watten & 1 & 32 & 1 & 1 & 1 & 1 & 3 \\
\hline $335-/ 953-$ & Ackergill & 1 & 32 & 1 & 1 & 1 & 1 & 2 \\
\hline \multirow{2}{*}{$3327 / 9512$} & Haster & 1 & 38 & 0.50 & 0.50 & 0 & 0 & $P$ \\
\hline & Combined site $\mathrm{c}$ & 3 & 34.0 & 0.83 & 0.83 & 0.67 & 0.67 & \\
\hline $3345 / 9447$ & Brickigore, Thrumster & 1 & 32 & 1 & 1 & 1 & 1 & 3 \\
\hline & Thrumster & 4 & 36.3 & 0.88 & 1 & 0 & 0 & $\mathrm{P}$ \\
\hline \multirow{2}{*}{$3346 / 9437$} & Sarclet & 6 & 36.0 & 1 & 1 & 0 & 0 & $P$ \\
\hline & Combined site d & 11 & 35.7 & 0.95 & 1 & 0.09 & 0.09 & \\
\hline
\end{tabular}


Table 1 Continued

\begin{tabular}{|c|c|c|c|c|c|c|c|c|}
\hline \multirow[b]{2}{*}{ Grid ref.* } & \multirow[b]{2}{*}{ Site $\dagger$} & \multirow[b]{2}{*}{$N$} & \multirow{2}{*}{$\begin{array}{l}2 n \\
\text { (mean) }\end{array}$} & \multicolumn{4}{|c|}{ Freq. of metacentric chromosomes } & \multirow[b]{2}{*}{ Refs $\ddagger$} \\
\hline & & & & 4.10 & 9.12 & 6.13 & 11.14 & \\
\hline $3235 / 9380$ & Smerlie 1 & 5 & 36.6 & 1 & 0.70 & 0 & 0 & $\mathbf{P}$ \\
\hline $3238 / 9379$ & Smerlie 2 & 3 & 36.0 & 1 & 1 & 0 & 0 & $\mathbf{P}$ \\
\hline $3239 / 9379$ & Smerlie 3 & 6 & 36.2 & 1 & 0.92 & 0 & 0 & $3, \mathrm{P}$ \\
\hline \multirow[t]{2}{*}{$3243 / 9357$} & Lybster & 2 & 36.0 & 1 & 1 & 0 & 0 & 3 \\
\hline & Combined site $\mathrm{e}$ & 16 & 36.3 & 1 & 0.88 & 0 & 0 & \\
\hline $3070 / 9201$ & Ousdale & 4 & 40.0 & 0 & 0 & 0 & 0 & $\mathbf{P}$ \\
\hline \multirow[t]{2}{*}{$3029 / 9166$} & Helmsdale & 1 & 40 & 0 & 0 & 0 & 0 & 3 \\
\hline & Combined site $\mathrm{f}$ & 5 & 40.0 & 0 & 0 & 0 & 0 & \\
\hline $2957 / 9107$ & Crakaig (site g) & 18 & 40.0 & 0 & 0 & 0 & 0 & $\mathbf{P}$ \\
\hline $2925 / 9078$ & Brora $($ site h) & 7 & 40.0 & 0 & 0 & 0 & 0 & $\mathbf{P}$ \\
\hline
\end{tabular}

*Longitude/latitude, to an accuracy of $100 \mathrm{~m}$ (or $1 \mathrm{~km}$, in some cases).

$\dagger$ The sample sizes for many sites are small. In order to provide a reasonable representation of frequency variation along the east-west and north-south transects (Figs 2 and 3, respectively), a lumping of data was considered essential. Along the east-west transect, sites were organized according to the longitudinal grid reference and sites were lumped with neighbouring locations $\leq 2 \mathrm{~km}$ away along the longitudinal axis. Additionally, data on single mice caught at East Mey, Shalmstry and Armadale were combined with data from the nearest sites (3.1, 3.7 and $9.2 \mathrm{~km}$ away along the longitudinal axis, respectively). Sites along the north-south transect were similarly ordered by latitudinal grid reference, with data on single mice from Lybster and Helmsdale lumped with data from the nearest locations 2.2 and $3.5 \mathrm{~km}$ away along the latitudinal axis, respectively. $\ddagger 1=$ Adolph \& Klein, 1981;2 = Brooker, 1982; $3=$ Scriven \& Brooker, 1990; $4=$ Searle, 1991; P=present study. There are errors in the interpretation of Brooker (1982), many of which were corrected by Scriven \& Brooker (1990). The data from Brooker (1992) recorded here are sites where only animals having 32 chromosomes were collected, which can be reliably considered to be homozygous metacentric for 4.10, 9.12,6.13 and 11.14.

consists of staggered clines. Both in an east-west direction (as shown previously) and north-south, transects reveal that the clines for metacentrics 4.10 and 9.12 are not coincident with those for 6.13 and 11.14 (Figs 2 and 3 ). Additionally, the cline for 6.13 is staggered from that for 11.14 along the east-west transect (Fig. 2) but apparently not along the north-south transect (Fig. 3).

An intriguing aspect of the staggered structure to the John o'Groats-standard hybrid zone is the occurrence of sites or regions dominated by individuals with a homozygous karyotype different from either pure race (Table 1). Along the east-west transect, mice from the vicinity of Castletown (Castletown, Mains of Olrig) tended to have 34 chromosomes (homozygous for metacentrics 4.10, 9.12 and 6.13; homozygous acrocentrics for 11 and 14), and mice from around Achiemore (Achiemore, Upper Bighouse, Bunahoun, Laidham) tended to have 36 chromosome karyotypes (homozygous for metacentrics 4.10 and 9.12, homozygous acrocentric for $6,11,13$ and 14; see Fig. 4). The occurrence of intermediate homozygotes is even more striking south of John o'Groats where there is a region $10 \mathrm{~km}$ wide, between Thrumster and Lybster, where 21 out of 27 individuals karyotyped ( 78 per cent) had a homozygous karyotype of 36 chromosomes (4.10, $9.12,6,11,13,14)$.

In the earlier study of Searle (1991), some individuals from Seater, Mains of Olrig and Achiemore displayed another type of chromosomal variant: the presence of a homogeneously staining region (HSR) on chromosome 1 (Traut et al., 1984). HSRs, which are produced when there is a massive gene amplification, are common in cancer cells but this is a unique heritable HSR (Traut et al., 1984). Among the new samples collected for the present study, four out of eight new individuals (two males, two females) from Seater, one female out of four individuals from Thrumster and one male out of 17 new individuals from Ribigill were heterozygous for the distinctively long HSR-bearing chromosome (Fig. 4). Of the three individuals from Bunahoun, one male was a heterozygote and another a homozygote for the long chromosome 1 . Thus, of the 214 mice karyotyped in this study and by Searle (1991), a total of $14 \mathrm{HSR} /$ + heterozygotes (seven males, seven females) and one HSR/HSR homozygote (a male) were recorded (overall recorded HSR frequency in the region: 0.037 ). However, higher frequencies are apparent at certain sites or groups of sites such as Seater $(0.176, n=17)$ and in the vicinity of Achie- 
(a)

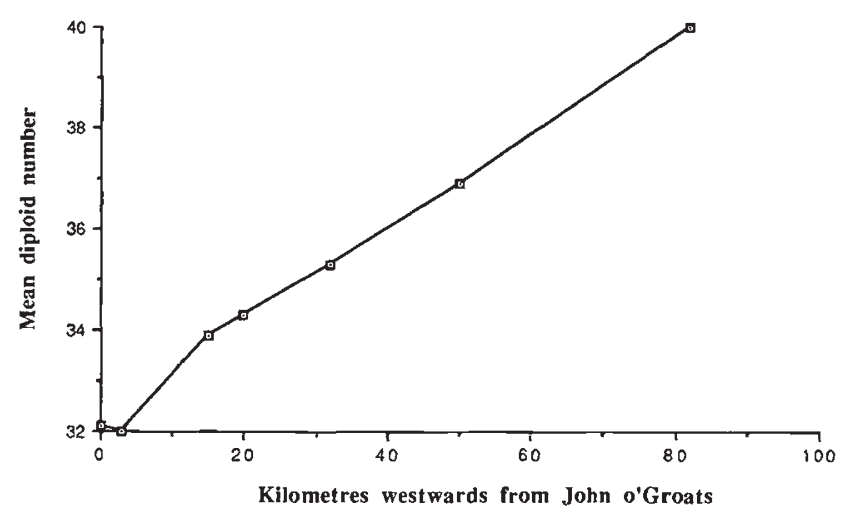

(b)

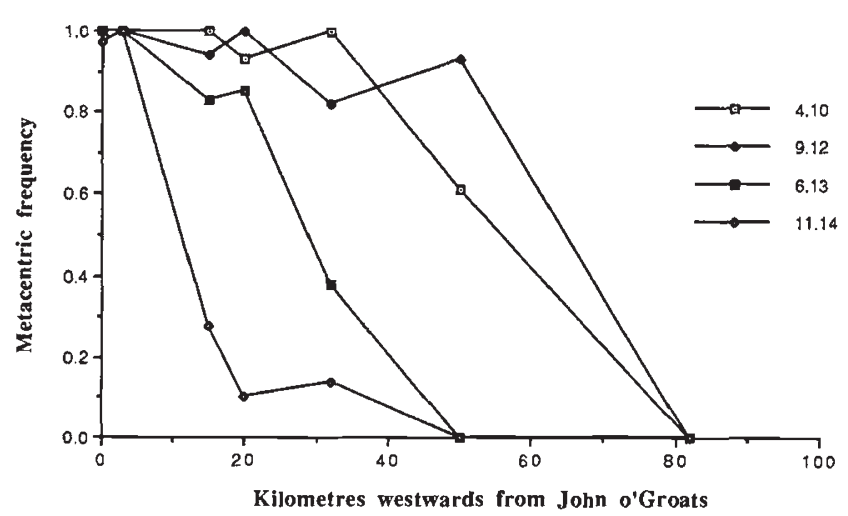

Fig. 2 Variation in (a) mean diploid number and (b) metacentric frequency following a transect along the coast in a westerly direction from John o'Groats. Distances reflect the west-southwest course of the coastline (see Fig. 1).

more $(0.086, n=35)$. These frequencies of the HSR variant are likely to be underestimates, as they were based on G-banded preparations. The variant is most easily detected after C-banding (Fig. 4), a technique for visualizing repetitive DNA (Sumner, 1972), which was not generally used in this study. However, slides from the HSR/+ heterozygote and HSR/HSR homozygote from Bunahoun and an HSR/+ heterozygote from Seater were stained by $\mathrm{C}$-banding and the presence of the HSR was confirmed (Fig. 4).

The HSR variant is found at a low frequency in sites throughout the distribution of Mus musculus, including other metacentric races of $M . m$. domesticus, but whether it is a neutral marker or has some physiological significance is unclear (Winking et al., 1991; Hübner, 1992).

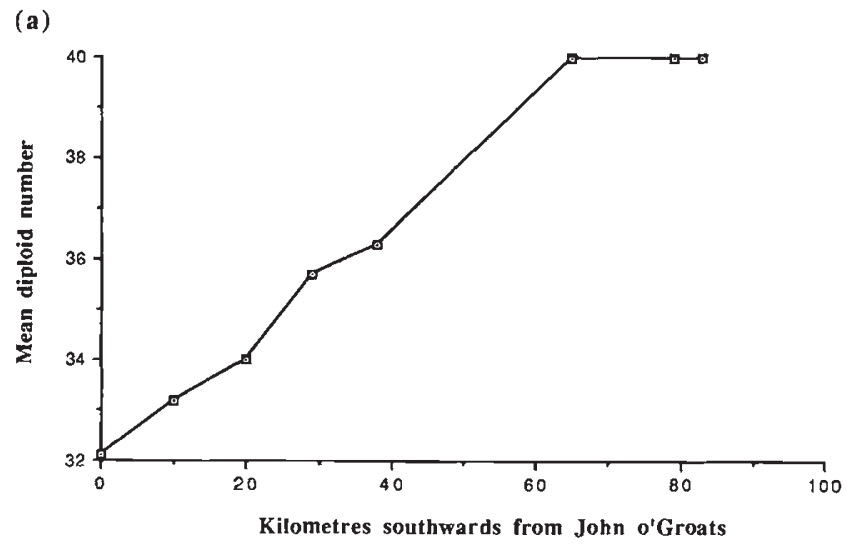

(b)

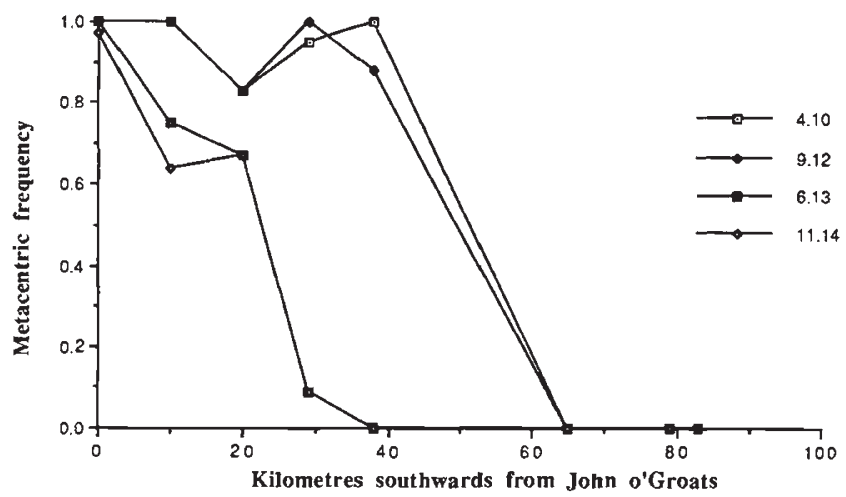

Fig. 3 Variation in (a) mean diploid number and (b) metacentric frequency following a transect along the coast in a southerly direction from John o'Groats. Distances reflect the south-west course of the coastline from Thrumster to Brora (see Fig. 1).

\section{Discussion}

\section{Patchiness within the hybrid zone}

The John o'Groats-standard hybrid zone is characterized by an increase in chromosome number and decrease in frequency of metacentrics going west or south of John o'Groats. One interesting feature of the zone is the occasional occurrence of individuals with a karyotype distinctly different from that expected within the geographical area in which they reside. Often these are samples of single individuals, which may indicate that they came from small populations. Certainly, the individual from Haster which had an unexpectedly acrocentric karyotype (Table 1) was the only individual caught from a farm after many nights of trapping (Ganem, G., personal communication); likewise for the 
(a)

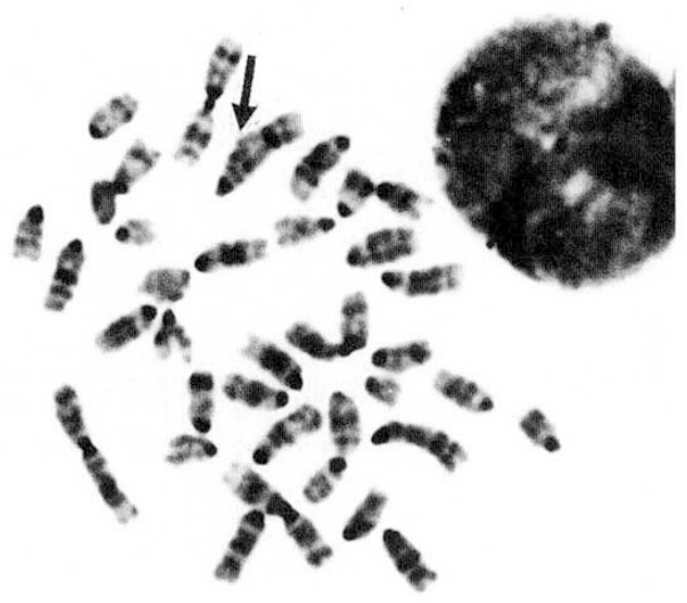

(b)

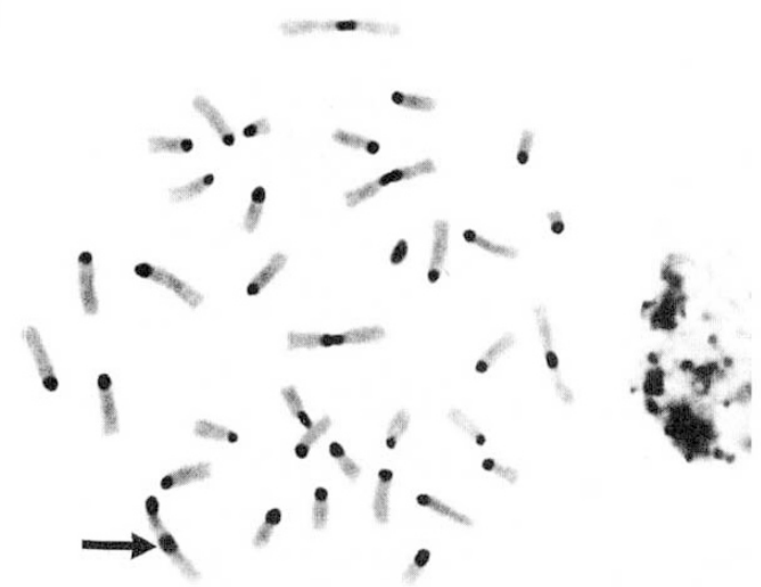

Fig. 4 Chromosome spreads from a 36-chromosome male from Bunahoun after staining by (a) G-banding and (b) C-banding. Note the two large metacentrics (4.10) and two smaller metacentrics (9.12); all other chromosomes are acrocentric. The centromeres of all chromosomes except the $\mathrm{Y}$ chromosome stain intensely by $\mathrm{C}$-banding, indicating the presence of pericentric satellite DNA. The Y chromosome and a region on the long chromosome 1 (arrow) also stain by C-banding but less intensely, presumably because the DNA is repetitive but not to the same 'extent' as the satellite DNA. The C-band on the long chromosome 1 is at precisely the position expected for the homogeneously staining region (HSR) described by Traut et al. (1984).

somewhat aberrant individual from Armadale (Searle, J. B., pers. obs.). There are two other instances where there is evidence that the unusual karyotypes are not geographically extensive. In $c a$. 1980, Brooker collected single mice from Dunnet 1 and Brickigore that had unexpectedly acrocentric and metacentric karyotypes, respectively. However, in 1992, we collected mice from very close sites (Dunnet 2, Thrumster) which had karyotypes much more in line with expectation. So, it would appear that instances of mice with a karyotype different from that expected for a particular geographic area are most likely derived from small propagules recently transported long distances by humans. There are no large patches of mice with karyotypes different from a single progression from one race to another, as observed, for instance, in the hybrid zone in Upper Valtellina (northern Italy) (Hauffe \& Searle, 1993). In the terminology of Searle (1993), the John o'Groats-standard hybrid zone is a 'staggered', rather than a 'mottled' hybrid zone.

\section{Association of races with geographic terrain}

One of the most striking features of the hybrid zone is the association between karyotype and terrain. The metacentrics 11.14 and 6.13 are essentially limited to the agricultural triangle between Thurso, Wick and John o'Groats (Fig. 1). The metacentrics 4.10 and 9.12 also occur in this region but extend along the agricultural coastal strip both to the south and west. Further along these coasts, where the villages become increasingly isolated and the terrain more mountainous, the mice have standard all-acrocentric karyotypes. Thus, within the region sampled, the John o'Groats race (and the metacentrics which characterize it) is found in terrain that is relatively warm, dry, prime agricultural land (particularly for cattle-rearing) while the standard race is limited to cold, wet, agriculturally poor areas (Anonymous, 1982).

It should be emphasized that this association between karyotype and a particular habitat type in a small geographic area need not imply that the members of the different races prefer or are adapted to different habitats. Further studies are required to establish whether this is the case.

The situation in Scotland is not a unique example of a link between a metacentric race and a particular habitat type in the house mouse. In Tunisia, Said \& Britton-Davidian (1991) have shown that a race with 22 chromosomes is limited to urban areas, while the standard race occurs in the surrounding rural habitat.

Looking at the overall distribution of metacentric races in $M . m$. domesticus, there is a concentration of such races in high altitude and coastal regions within Europe (Bauchau, 1990; Searle et al., 1990). One would expect particularly small populations in such areas, which may promote fixation of new chromosomal rearrangements (Lande, 1979). However, at a local level in northern Scotland, it is striking that the John o'Groats race apparently occurs in the prime house mouse habitat while the standard race occurs in the poorer terrain. So, while the John o'Groats race is a small race making contact with the much more widespread standard race (Searle, 1991), the metacentric 
John o'Groats race is likely to be occurring at higher density locally. Likewise, in alpine Switzerland Hübner (1992) found that the races with most metacentrics in their karyotypes tend to occur along the main river valleys, while races with more acrocentric karyotypes (including the standard race) occur in the higher altitude (and agriculturally poorer) side valleys. Clearly there is a need to examine whether the occurrence of metacentric races in certain habitats at the local level reflects adaptational differences between metacentric and acrocentric races, or whether the population dynamics of mice in those habitats is particularly favourable for the formation and/or maintenance of metacentric races.

\section{The origin and evolution of the hybrid zone}

We assume that the chromosomal clines in the John o'Groats-standard hybrid zone are maintained by a selection-dispersal balance (Barton \& Hewitt, 1985). Studies on small mammals indicate that, as a result of meiotic aberrations, heterozygotes for $\mathrm{Rb}$ fusions are generally less fertile than homozygotes, albeit to a very small degree in the case of heterozygotes for one or two fusions (Searle, 1993). The better documented clines in the John o'Groats-standard hybrid zone (Figs 2 and 3) are approximately $20 \mathrm{~km}$ wide (inverse of maximum slope). This does indeed suggest very weak selection against heterozygotes $\left(2 \times 10^{-5}\right.$, assuming a dispersal distance of $30 \mathrm{~m}$ as estimated from markrelease-recapture studies: Barton \& Hewitt, 1981; Lidicker \& Patton, 1987), consistent with meiotic studies on wild-caught mice from the zone (Wallace et al., 1992).

Normally, multiple clines maintained by a selectiondispersal balance are coincident within a hybrid zone (Barton \& Hewitt, 1985), but this is clearly not the case in the contact between the John o'Groats race and the standard race in the house mouse. There are various possible reasons why there should be non-coincidence of clines within a hybrid zone, as discussed by Barton \& Bengtsson (1986), Searle (1986, 1991), Harrison (1990) and Butlin et al. (1991).

The precise nature of the non-coincidence of clines in the John o'Groats-standard zone is as follows. The new data presented in this paper show that the clines for metacentrics 11.14 and 6.13 are strikingly staggered from the clines for 9.12 and 4.10 both south and west of John o'Groats (Figs 2 and 3). In the region around Thrumster and Lybster (Fig. 1, Table 1) most individuals are homozygotes for chromosomes 9.12 and $4.10(2 n=36)$. This is also one of the most common karyotypes in the vicinity of Achiemore on the northern coast. As this 36-chromosome comple- ment occurs commonly over an area perhaps as large as $100 \mathrm{~km}^{2}$, there is some justification in considering individuals with this karyotype as belonging to a distinct karyotypic race (the John o'Groats race occurs commonly over an area of about $400 \mathrm{~km}^{2}$ ). To help understand the origin of the staggered chromosomal hybrid zone in Caithness and Sutherland we will reduce the problem to a consideration of the alternative origins of the '36-chromosome race'.

One possibility is that the 36-chromosome form occupied a substantial part of Caithness before the John o'Groats race originated and has persisted ever since. Metacentrics 4.10 and 9.12 (but not 6.13 or 11.14) are found on the nearby islands of Orkney (Adolph \& Klein, 1981; Brooker, 1982; Berry et al., 1992) and so these metacentrics either evolved in Orkney and colonized Caithness or vice versa. Thus, the populations with 36 chromosomes seen today could represent the present distribution of an ancestral metacentric race, while the 32-chromosome John o'Groats race could be a currently more widespread derivative characterized by two new metacentrics, 6.13 and 11.14. Furthermore, for this hypothesis to accommodate recent molecular data, the present contact between the race with 36 chromosomes and the standard race would most reasonably be viewed as secondary. Mice from John o'Groats $(2 n=32)$ are similar to those of Orkney in terms of mtDNA, Y chromosome DNA and allozymes, while those from Ribigill $(2 n=40)$ appear to have affinities with mice found in southern Britain (Jones, 1990; Nachman, M. W. King, P., Ganem, G. \& Searle, J. B., unpublished observation).

An alternative scenario is that the form with 36 chromosomes currently seen in Caithness arose following secondary contact between the John o'Groats and standard races, i.e. by a process described as 'zonal raciation' (Searle, 1991, 1993). If a typical multilocus hybrid zone was formed, with all four metacentric clines coincident, the clines may have become separated for one of two reasons discussed in detail by Searle (1991).

1 If the forces which tend to hold together clines of heterozygous disadvantage in a hybrid zone (Barton \& Hewitt, 1985) were weak in the John o'Groats-standard contact, the clines could have rather easily become separated in response to, say, changes in population density.

2 If the unfitness of heterozygotes for three or four fusions was notably greater than that for single or double heterozygotes, the separation of the clines may have been favoured as a process to reduce the frequency of the unfit multiple heterozygotes. 
Although there is no substantial patchiness in the John o'Groats-standard hybrid zone at present, suggesting that there is currently no major isolation of populations within the zone, there may have been such isolates in the past. If the John o'Groats race and the standard race both contributed to such a temporary isolate after secondary contact, 36 chromosome homozygotes may have arisen and become fixed in an analogous fashion to that described for a new race in the Upper Valtellina hybrid zone (Hauffe \& Searle, 1993). As house mouse habitat improved in the vicinity of the John o'Groats-standard hybrid zone, this 36-chromosome form may have spread into previously mousefree territory to occupy a substantial intermediate range between the 32-chromosome and 40-chromosome races. The initial colonization of Scandinavia by house mice is likewise thought to have involved a recombinant form, in this case derived from the Mus musculus musculus-M. m. domesticus hybrid zone in Germany (Gyllensten \& Wilson, 1987).

Clearly, all the models presented above are simplifications and do not consider, for instance, why the 6.13 and 11.14 clines are staggered along the east-west transect but not the north-south transect, or why the populations dominated by 36-chromosome homozygotes occupy essentially disjunct distributions along the northern and western coastal strips of Caithness and Sutherland. However, despite such complexities, we expect that further geographical sampling, mathematical modelling, etho-ecological studies and molecular analyses will ultimately help us choose between the various possible hypotheses to explain the staggered John o'Groats-standard hybrid zone in the house mouse.

\section{Acknowledgements}

J. B. S. and G. G. were funded by the Royal Society of London and the French Foreign Ministry (Bourse 'Lavoisier'), respectively. Y. Y. N. acknowledges the support of the Department of Zoology, University of Oxford in permitting her to do this work as part of an M.Sc. (taught) course in Biology. We are very grateful to the Percy Sladen Fund (Linnean Society of London) for financial help with field work expenses. Tim Jones and Paul Alibert provided invaluable assistance in the field and $\mathrm{Mr}$ Jones also helped to maintain mice in the laboratory. This study would not have been possible without the tolerance and generosity of farmers in Caithness and Sutherland.

\section{References}

ADOLPH, S. AND KLEIN, J. 1981. Robertsonian variation in Mus musculus from central Europe, Spain, and Scotland. J. Hered., 72, 219-222.
ANONYMOus. 1982. The Ordnance Survey Atlas of Britain. Ordnance Survey, Southampton.

BARTON, N. H. AND BENGSTSSON, B. O. 1986. The barrier to genetic exchange between hybridising populations. Heredity, 56, 357-376.

BARTON, N. H. AND HEWITT, G. M. 1981. A chromosomal cline in the grasshopper Podisma pedestris. Evolution, 35, 1008-1018.

BARTON, N. H. AND HEWITT, G. M. 1985. Analysis of hybrid zones. Annu. Rev. Ecol. Syst., 16, 113-148.

BaUchau, v. 1990. Phylogenetic analysis of the distribution of chromosomal races of Mus musculus domesticus Rutty in Europe. Biol. J. Linn. Soc., 41, 171-192.

BERRY, R. J., BERRY, A. J., ANDERSON, J. J. C. AND SCRIVEN, P. 1992. The house mice of Faray, Orkney. J. Zool., 228, 233-246.

BROOKER, P. C. 1982. Robertsonian translocations in Mus musculus from N. E. Scotland and Orkney. Heredity, 48, 305-309.

BUtlin, R. K., RITCHIE, M. G. AND HEWITT, G. M. 1991. Comparisons among morphological characters and between localities in the Chorthippus parallelus hybrid zone (Orthoptera: Acrididae). Phil. Trans. R. Soc. London Ser. $B, 334,297-308$.

GYLLENSTEN, U. AND WILSON, A. C. 1987. Interspecific mitochondrial DNA transfer and the colonization of Scandinavia by mice. Genet. Res., 49, 25-29.

HARRISON, R. G. 1990. Hybrid zones: windows on the evolutionary process. Oxford Surveys Evol. Biol., 7, 69-128.

HAUFFE, H. C. AND SEARLE, J. B. 1993. Extreme karyotypic variation found in a hybrid zone between five chromosomal races of Mus musculus domesticus in Upper Valtellina, northern Italy. The tobacco mouse revisited. Evolution (in press).

HÜBNER, R. 1992. Chromosomal and biochemical variation in wild mice from Switzerland: relevance for models of chromosomal evolution in European house mice. Ph.D Thesis, University of Oxford.

JONES, C. S. 1990. Mitochondrial DNA variation in British house mice (Mus domesticus Rutty). Ph.D Thesis, University of London.

LANDE, R. 1979. Effective deme size during long-term evolution estimated from rates of chromosomal rearrangement. Evolution, 33, 234-251.

LIDICKER, w. Z. AND PATTON, J. L. 1987. Patterns of dispersal and genetic structure in populations of small rodents. In: Chepko-Sade, B. D. and Halpin, Z. T. (eds) Mammalian Dispersal Patterns, University of Chicago Press, pp. 144-161.

LYON, M. F. AND SEARLE, A. G. (eds) 1989. Genetic Variants and Strains of the Laboratory Mouse. Oxford University Press, Oxford.

SAID, K. AND BRITTON-DAVIDIAN, J. 1991. Genetic differentiation and habitat partition of Robertsonian house mouse populations (Mus musculus domesticus) of Tunisia. J. Evol. Biol., 4, 409-427.

SCRIVEN, P. N. AND BROOKER, P. C. 1990. Caithness revisited: Robertsonian chromosome polymorphism in Caithness house mice. Heredity, 64, 25-27.

SEARLE, J. B. 1986. Factors responsible for a karyotypic polymorphism in the common shrew, Sorex araneus. Proc. $R$. Soc. London. Ser. B, 229, 277-298. 
SEARLE, J. B. 1991. A hybrid zone comprising staggered chromosomal clines in the house mouse (Mus musculus domesticus). Proc. R. Soc. Lond. Ser. B, 246, 47-52.

SEARLE, J. B. 1993. Chromosomal hybrid zones in eutherian mammals. In: Harrison, R. G. (ed.) Hybrid Zones and the Evolutionary Process, Oxford University Press, Oxford, pp. 309-353.

SEARLE, J. B., HÜBNER, R., WALLACE, B. M. N. AND GARAGNA, S. 1990. Robertsonian variation in wild mice and shrews. Chromosomes Today, 10, 253-263.

SUMNER, A. T. 1972. A simple technique for demonstrating centromeric heterochromatin. Expl. Cell Res., 75, 304-306.
TRAUT, W., WINKING, H. AND ADOLPH, s. 1984. An extra segment in chromosome 1 of wild Mus musculus: a C-band positive homogeneously staining region. Cytogenet. Cell Genet., 38, 290-297.

WALlACE, B. M. N., SEARLE, J. B. AND EVERETT, C. A. 1992. Male meiosis and gametogenesis in wild house mice (Mus musculus domesticus) from a chromosomal hybrid zone; a comparison between 'simple' Robertsonian heterozygotes and homozygotes. Cytogenet. Cell Genet., 61, 211-220.

WINKING, H., BOSTELMANN, H. AND FREDGA, K. 1991. Incidence of double-banded HSRs in chromosome 1 of the house mouse, Mus musculus musculus, from Oland (Sweden): a population study. Hereditas, 1 14, 111-116. 